\title{
Factors associated with herd bulk milk composition and technological traits in the Italian dairy industry
}

\author{
A. Benedet, ${ }^{*}$ C. L. Manuelian, ${ }^{*}$ M. Penasa, ${ }^{*}$ M. Cassandro, ${ }^{*}$ F. Righi, $†$ M. Sternieri,‡ P. Galimberti,‡ \\ A. V. Zambrini, $\ddagger$ and M. De Marchi*1 \\ *Department of Agronomy, Food, Natural Resources, Animals and Environment, University of Padova, Viale dell'Università 16, \\ 35020 Legnaro (PD), Italy \\ †Department of Veterinary Science, University of Parma, Via del Taglio 10, 43126 Parma, Italy \\ ‡Granarolo S.p.A., Via Cadriano 27/2, 40127 Bologna, Italy
}

\begin{abstract}
The aim of the present study was to investigate sources of variation of milk composition and technological characteristics routinely collected in field conditions in the Italian dairy industry. A total of 40,896 bulk milk records from 620 herds and 10 regions across Italy were analyzed. Composition traits were fat, protein, and casein percentages, urea content, and somatic cell score; and technological characteristics were rennet coagulation time, curd firming time, curd firmness $30 \mathrm{~min}$ after rennet addition to milk, and titratable acidity. Data of herd bulk milks were analyzed using a model that included fixed effects of region, herd nested within region, and season of milk analysis. An average good milk quality was reported in the dairy industry (especially concerning fat, protein, and casein percentages), and moderate to high correlations between composition and technological traits were observed. All factors included in the statistical model were significant in explaining the variation of the studied traits except for region effect in the analysis of casein and somatic cell score. Northeast and central-southern Italian regions showed the best performance for composition and technological features, respectively. Traits varied greatly across regions, which could reflect differences in herd management and strategies. Overall, less suitable milk for dairy processing was observed in summer. Results of the present study suggested that a constant monitoring of technological traits in the dairy industry is necessary to improve production quality at herd level and it may be a way to segregate milk according to its processing characteristics.
\end{abstract}

Key words: dairy industry, Italian region, milk composition, milk technological trait

Received February 13, 2017.

Accepted October 2, 2017.

${ }^{1}$ Corresponding author: massimo.demarchi@unipd.it

\section{INTRODUCTION}

Cheese production and export are constantly increasing in Europe (ISMEA, 2016) and Italy is one of the most important European producers, with about $1.2 \times$ $10^{6} \mathrm{t}$ of cheese produced in 2013 (Pieri, 2014). About $75 \%$ of milk is used for cheese making, $50 \%$ of which is destined to manufacture Protected Designation of Origin (PDO) products. The contribution of the dairy sector to food industry income is about $11 \%$, counting more than 2,000 operative dairy industries (Pieri, 2014). Therefore, from an economic point of view, it is important to valorize the milk suitable for cheese manufacturing and the efficiency of the dairy chain (Pieri, 2014).

To satisfy the increasing cheese demand and to guarantee more products with high added value in the market, the dairy industry is increasingly focusing on technological quality of milk (Cassandro, 2003). The technological quality summarizes the ability of milk to react to the clotting enzyme in due time and form a curd with an adequate firmness, and it is mainly evaluated through milk coagulation properties (MCP, namely rennet coagulation time, RCT; curd firming time, $\mathbf{k}_{\mathbf{2 0}}$; and curd firmness 30 min after rennet addition to milk, $\mathbf{a}_{\mathbf{3 0}}$ ) and titratable acidity (TA; Malacarne et al., 2006; Cassandro et al., 2008; Penasa et al., 2016). In dairy cows, these traits are affected by several factors, such as milk chemical composition (Malacarne et al., 2006; Jõudu et al., 2008; Toffanin et al., 2012), breed (De Marchi et al., 2007, 2008; Penasa et al., 2014), individual animal (Cassandro et al., 2008; Vallas et al., 2010; Tiezzi et al., 2013), feeding and management (Righi et al., 2007; Toffanin et al., 2012; Comino et al., 2015), lactation stage (Ikonen et al., 2004; Tyrisevä et al., 2004; Penasa et al., 2014), parity (Ikonen et al., 2004; Penasa et al., 2014), and season (De Marchi et al., 2007; Penasa et al., 2016). Therefore, milk composition and technological characteristics are indicators of dairy manufacture efficiency 
(Summer et al., 2002; Pretto et al., 2013). Previous studies on milk technological characteristics have been carried out at individual cow level for phenotypic and genetic purposes. To our knowledge, only a few studies have investigated the variation of milk technological traits at bulk milk level using field data (De Marchi et al., 2007; Summer et al., 2014; Penasa et al., 2016), but those reports were based on small sample size or were conducted in a restricted geographical area.

Milk quality payment system in Italy is mainly based on fat percentage, protein (or casein) percentage, SCC, and bacterial count, which derive from routine farm bulk milk recording. This system seeks to reward or penalize dairy farmers according to the quality of delivered milk. Nevertheless, MCP and TA are important traits when milk is used for cheese production because they are associated with dairy industry efficiency and thus with farm profitability (Pretto et al., 2013; Cassandro et al., 2016). In Italy, MCP and TA have been included in the payment systems of Parmigiano Reggiano (Summer et al., 2015) and Trentingrana (Penasa et al., 2016) cheese production. In particular, since 2015 the laboratory of the Trentingrana-Consorzio dei Caseifici Sociali Trentini s.c.a (Trento, Italy) has adopted mid-infrared spectroscopy to predict RCT and $\mathrm{a}_{30}$ on bulk milk samples routinely collected from each associated herd; the predicted traits are combined in a standardized index of milk aptitude to coagulate and used to reward or penalize farmers for milk coagulation ability (N. Cologna, Trentingrana-Consorzio dei Caseifici Sociali Trentini s.c.a, Trento, Italy, personal communication).

The aim of the present study was to investigate sources of variation of composition and technological traits of bulk milk across several Italian regions using field data collected by the biggest Italian dairy industry. Results will help the industry to incorporate MCP in the payment system and segregate milk in relation to its aptitude to coagulate.

\section{MATERIALS AND METHODS}

\section{Data Collection}

Data of bulk milk analysis of 627 herds located in 11 Italian regions were retrieved from the database of the central laboratory of Granarolo S.p.A. (Bologna, Emilia-Romagna, Italy) from November 2015 to October 2016. Granarolo S.p.A. is the most important dairy industry in Italy and it collects milk from herds located in north, central, and south of the country. According to the Italian Breeders Association (AIA, 2015), the regions included in the present study are those producing the largest amount of Italian milk. Bulk milk samples are routinely collected by Granarolo S.p.A. in the associated herds, and the results of the laboratory analysis are used to reward or penalize milk payment.

\section{Milk Analysis}

Bulk milk samples $(50 \mathrm{~mL})$ were collected in the farms and $0.1 \mathrm{~mL}$ of azidiol preservative was added; the azidiol was prepared at the central laboratory of Granarolo S.p.A. Internal trials showed that less than $0.3 \mathrm{~mL}$ of azidiol in $50 \mathrm{~mL}$ of milk does not alter results from mid-infrared analysis. Azidiol composition per 1,000 mL was chloramphenicol (1.5 g), anhydrous trisodium citrate $(34 \mathrm{~g})$, sodium azide (36 g), bromophenol blue $(0.35 \mathrm{~g})$, ethanol $(10 \mathrm{~mL})$, and demineralized water (balanced). Samples were transported to the central laboratory of Granarolo S.p.A. and stored at $4^{\circ} \mathrm{C}$ until analysis, which was conducted within 5 d from milk sampling. All bulk milk samples were analyzed in the same laboratory (central laboratory of Granarolo S.p.A.) through mid-infrared spectroscopy prediction models available on MilkoScan FT6000 (Foss Electric A/S, Hillerød, Denmark) to assess traditional composition (fat, protein, and casein percentages, and urea content) and technological traits $\left(\mathrm{RCT}, \mathrm{k}_{20}, \mathrm{a}_{30}\right.$, and TA). Milk quality traits were processed following the standard methods used in official milk-recording schemes for fat, protein, casein, and urea. Somatic cell count was determined by flow cytometers with Fossomatic (Foss Electric A/S) and values of SCC were transformed to SCS through the formula SCS $=3+$ $\log _{2}(\mathrm{SCC} / 100,000)$. Milk technological traits were determined using the commercial prediction models provided by Foss (Foss Electric A/S), based on De Marchi et al. (2012, 2013) and Toffanin et al. (2015). These prediction models were installed in the Foss Integrator Software of MilkoScan FT6000 in the Granarolo S.p.A. central laboratory in February 2015.

\section{Data Editing and Statistical Analysis}

The original data set of herd bulk milk samples ( $\mathrm{n}=$ 43,397) was edited as follows: urea between 2 and 48 $\mathrm{mg} / 100 \mathrm{~mL}$ of milk, RCT greater than $0, \mathrm{a}_{30}$ between 0.01 and $35 \mathrm{~mm}$, and TA between 2.90 and 4.00 SoxhletHenkel degrees $\left({ }^{\circ} \mathbf{S H}\right) / 50 \mathrm{~mL}$. Editing for SCS and fat, protein, and casein percentage was not necessary. Herds with fewer than 5 milk analyses were discarded as well as one region with only one farm. After data editing, 40,896 milk samples from 620 herds and 10 regions were available for statistical investigation.

A preliminary analysis showed that all studied traits were normally distributed. Descriptive statistics of and Pearson correlations between traits were obtained 
Table 1. Descriptive statistics of quality and technological traits of bulk milk samples $(\mathrm{n}=40,896)$

\begin{tabular}{lrrrc}
\hline Item & Mean & SD & CV (\%) & Interquartile range \\
\hline Quality trait & & & & \\
Fat (\%) & 3.86 & 0.26 & 6.7 & 0.32 \\
Protein (\%) & 3.34 & 0.16 & 4.8 & 0.18 \\
Casein (\%) & 2.58 & 0.13 & 5.0 & 0.15 \\
Urea (mg/100 mL) & 23.38 & 5.85 & 25.0 & 0.50 \\
SCS & 4.09 & 0.69 & 16.9 & 3.35 \\
Technological trait & & & & 0.73 \\
RCT (min) & 23.39 & 2.50 & 10.7 & 7.85 \\
$\mathrm{k}_{20}(\mathrm{~min})$ & 7.17 & 0.57 & 7.9 & 0.14 \\
a $_{30}(\mathrm{~mm})$ & 11.51 & 5.67 & 49.3 & 3.5 \\
TA $\left.{ }^{\circ} \mathrm{SH} / 50 \mathrm{~mL}\right)^{2}$ & 3.42 & 0.12 & & \\
\hline
\end{tabular}

${ }^{1} \mathrm{RCT}=$ rennet coagulation time; $\mathrm{k}_{20}=$ curd firming time; $\mathrm{a}_{30}=$ curd firmness 30 min after rennet addition to milk; $\mathrm{TA}=$ titratable acidity.

${ }^{2 \circ} \mathrm{SH}=$ Soxhlet-Henkel degree.

through the MEANS and CORR procedures of SAS (v. 9.4, SAS Institute Inc., Cary, NC), respectively. Sources of variation of milk composition and technological traits were investigated using the GLM procedure of SAS according to the following linear model:

$$
y_{i j k l}=\mu+\operatorname{region}_{i}+\operatorname{herd}_{j}(\text { region })_{i}+\operatorname{season}_{k}+\varepsilon_{i j k l}
$$

where $y_{i j k l}$ is the dependent variable (fat percentage, casein percentage, urea content, SCS, RCT, $\mathrm{k}_{20}, \mathrm{a}_{30}$, or $\mathrm{TA}) ; \mu$ is the overall intercept of the model; region ${ }_{i}$ is the fixed effect of the $i$ th Italian region $(i=1$ to 10$)$; $\operatorname{herd}_{j}(\text { region })_{i}$ is the fixed effect of the $j$ th herd $(j=1$ to $620)$ nested within the $i$ th Italian region; $\operatorname{season}_{k}$ is the fixed effect of the $k$ th 2 mo class of sample analysis $(k=$ 1 to 6 , where $1=$ November to December; $2=$ January to February; $3=$ March to April; $4=$ May to June; $5=$ July to August; $6=$ September to October); and $\varepsilon_{i j k l}$ is the random residual $\sim N\left(0, \sigma^{2}{ }_{\mathrm{e}}\right)$, where $\sigma^{2}{ }_{\mathrm{e}}$ is the residual variance. Region effect was tested using herd within region as the error term, whereas the other fixed effects were tested on the residual. Multiple comparison of least squares means was performed for the effects of region and season using Bonferroni's test $(P<0.05)$.

\section{RESULTS AND DISCUSSION}

\section{Characterization of Bulk Milk Samples}

Descriptive statistics of milk quality and technological traits are shown in Table 1. Overall, milk traditional traits indicated good quality of milk collected by Granarolo S.p.A. dairy industry, being the average fat, protein, and casein equal to $3.86,3.34$, and $2.58 \%$, respectively. The coefficient of variation $(\mathbf{C V})$ of these characteristics was quite low and ranged between $4.8 \%$ (protein percentage) and $6.7 \%$ (fat percentage). Somatic cell score and urea content averaged 4.09 and
$23.38 \mathrm{mg} / 100 \mathrm{~mL}$, respectively (Table 1), and their variation (16.9 and 25\%) was greater than that of the other quality traits. Average milk chemical composition was similar to that reported by other studies on bulk milk samples (Summer et al., 2002; De Marchi et al., 2007; Penasa et al., 2016). The mean and CV of urea content were similar to findings of Arunvipas et al. (2004) in bulk milk; those authors found that urea nitrogen averaged $11.79 \mathrm{mg} / \mathrm{dL}$ (about $25.23 \mathrm{mg} / 100$ $\mathrm{mL}$ of urea), with a CV of $24.8 \%$. According to RajalaSchultz and Saville (2003), Arunvipas et al. (2004), and Vallas et al. (2010), the urea variability can be related to different feeds, quality of the rations, and feeding procedures used in the dairy herds. Moreover, it can be connected to nonnutritional factors such as productivity differences across herds, DIM, changes of season and parity, or different milk sampling times following feeding. Among these variables, diet characteristics are responsible for a large part of the differences.

Concerning milk technological traits, RCT, $\mathrm{k}_{20}, \mathrm{a}_{30}$, and TA averaged $23.39 \mathrm{~min}, 7.17 \mathrm{~min}, 11.51 \mathrm{~mm}$, and $3.42{ }^{\circ} \mathrm{SH} / 50 \mathrm{~mL}$, respectively (Table 1 ), and the CV ranged from $3.5 \%$ (TA) to $49.3 \%\left(\mathrm{a}_{30}\right)$. Several authors observed similar means for TA and $\mathrm{k}_{20}$ in bulk milk, but shorter RCT (13.5 to $22.1 \mathrm{~min}$ ) and firmer curd (14.5 to $27.1 \mathrm{~mm}$ ) compared with our findings (i.e., better MCP; De Marchi et al., 2007; Toffanin et al., 2012; Penasa et al., 2016). Overall, coagulation properties resulted poorer than predicted values reported by other authors in individual milk (Tiezzi et al., 2013; Penasa et al., 2014).

Correlation coefficients ( $\mathbf{r}$ ) between quality and technological traits were significant $(P<0.001)$, except for urea with $\mathrm{a}_{30}$ (results not shown), and they ranged, in absolute value, from 0.22 to 0.66 . The strongest and most favorable relationship was observed between casein and $\mathrm{k}_{20}(\mathrm{r}=-0.66)$. Casein was favorably correlated with $\mathrm{RCT}(\mathrm{r}=-0.24), \mathrm{a}_{30}(\mathrm{r}=0.40)$, and TA 
$(\mathrm{r}=0.50)$, and fat was favorably correlated with RCT $(\mathrm{r}=-0.30), \mathrm{k}_{20}(\mathrm{r}=-0.43), \mathrm{a}_{30}(\mathrm{r}=0.30)$, and TA $(\mathrm{r}=0.24)$. These results reinforce the fundamental role of casein (Summer et al., 2002; Jõudu et al., 2008; Toffanin et al., 2012) and fat (Pretto et al., 2013) on MCP. Overall, we obtained stronger relationships of technological traits with fat, protein, and casein percentages than those reported in the literature (Bittante et al., 2012). In bulk milk samples, Penasa et al. (2016) reported positive and close to zero correlations between RCT and fat percentage $(r=0.01)$, and RCT and casein percentage $(r=0.06)$. The same authors described favorable relationships of casein with $\mathrm{k}_{20}(\mathrm{r}=-0.34)$, $\mathrm{a}_{30}(\mathrm{r}=0.26)$, and TA $(\mathrm{r}=0.43)$. In studies that dealt with individual cow milk, Cassandro et al. (2008) and Toffanin et al. (2015) observed weak relationships of RCT with fat $(\mathrm{r}=-0.11$ and -0.08 , respectively) and casein $(\mathrm{r}=-0.19$ and -0.10 , respectively). Although urea and SCS were significantly $(P<0.001)$ correlated with MCP, the magnitude of the relationship was low ( -0.11 to -0.02 and -0.15 to 0.07 , respectively), in agreement with Vallas et al. (2010), Toffanin et al. (2015), and Penasa et al. (2016).

Results from the ANOVA for quality and technological traits are summarized in Table 2. The coefficient of determination $\left(\mathbf{R}^{2}\right)$ ranged from 0.51 (urea) to 0.71 (casein) for quality traits, and from 0.34 (RCT) to 0.55 $\left(\mathrm{k}_{20}\right)$ for technological traits. All effects were significant $(P<0.01)$ in explaining the variation of the studied traits, with the exception of region for casein and SCS, which approached significance $(P<0.10)$. According to type III sum of squares (Table 2), herd nested within region was the most important effect to explain the variability of the studied traits, followed by season of milk analysis.

\section{Effects of Region and Herd}

In this study, each region $(\mathbf{R})$ included a different number of herds: $\mathrm{R}_{1}$ (198), $\mathrm{R}_{9}$ (146), $\mathrm{R}_{4}$ (113), $\mathrm{R}_{6}(42)$, $\mathrm{R}_{10}$ (39), $\mathrm{R}_{2}$ (28), $\mathrm{R}_{7}(23), \mathrm{R}_{3}(12), \mathrm{R}_{5}$ (10), $\mathrm{R}_{8}$ (9). Northern regions were from $R_{1}$ to $R_{4}$, central regions were from $R_{5}$ to $R_{7}$, and southern regions were from $R_{8}$ to $\mathrm{R}_{10}$. Milk variability, based on least squares means, for traditional and technological traits across regions is displayed in Figure 1 and Figure 2, respectively. Fat (Figure 1A) and SCS (Figure 1D) revealed a similar pattern in northern and southern regions. The greatest values of fat and SCS were achieved in northern regions and the lowest in the south. For SCS, unfavorable values were also observed in the central regions. Casein (Figure 1B) and urea (Figure 1C) showed a similar pattern with higher values estimated in the northern and the southern regions, and lower values in the central regions. However, we observed a high variability for the traditional traits within each region (Figure 3). According to the interquartile range, fat (Figure 3A) and casein (Figure 3B) exhibited the lowest variability in $R_{5}$ and $R_{2}$, respectively, and the greatest in $R_{3}$. For urea (Figure 3C) and SCS (Figure 3D) the region with the greatest variability was $R_{5}$, and those with the lowest variability were $R_{3}$ and $R_{8}$ for urea and SCS, respectively.

The RCT (Figure 2A) and $\mathrm{k}_{20}$ (Figure 2B) showed a similar pattern, which agrees with the high positive correlation estimated between these 2 traits $(r=0.75$;

Table 2. Results from ANOVA ${ }^{1}$ for quality and technological traits of bulk milk samples

\begin{tabular}{|c|c|c|c|c|c|c|c|c|}
\hline \multirow[b]{2}{*}{ Item } & \multicolumn{6}{|c|}{ Effect } & \multirow[b]{2}{*}{$\mathrm{R}^{2}$} & \multirow[b]{2}{*}{ RMSE } \\
\hline & SS & $P$-value & SS & $P$-value & SS & $P$-value & & \\
\hline \multicolumn{9}{|l|}{ Quality trait } \\
\hline Fat (\%) & 57.88 & ** & 1,359 & $* * *$ & 450.8 & $* * *$ & 0.68 & 0.15 \\
\hline SCS & 238.4 & $\dagger$ & 9,562 & $* * *$ & 443.4 & $* * *$ & 0.53 & 0.47 \\
\hline \multicolumn{9}{|l|}{ Technological trait ${ }^{2}$} \\
\hline $\mathrm{RCT}(\min )$ & 6,348 & $* * *$ & 65,988 & $* * *$ & 13,289 & $* * *$ & 0.34 & 2.04 \\
\hline $\mathrm{k}_{20}(\min )$ & 544.8 & $* * *$ & 5,297 & $* * *$ & 1,236 & $* * *$ & 0.55 & 0.38 \\
\hline $\mathrm{a}_{30}(\mathrm{~mm})$ & 33,388 & $* * *$ & 302,564 & $* * *$ & 194,598 & $* * *$ & 0.40 & 4.42 \\
\hline $\mathrm{TA}\left({ }^{\circ} \mathrm{SH} / 50 \mathrm{~mL}\right)^{3}$ & 14.26 & $* * *$ & 225.9 & $* * *$ & 48.55 & $* * *$ & 0.52 & 0.08 \\
\hline
\end{tabular}



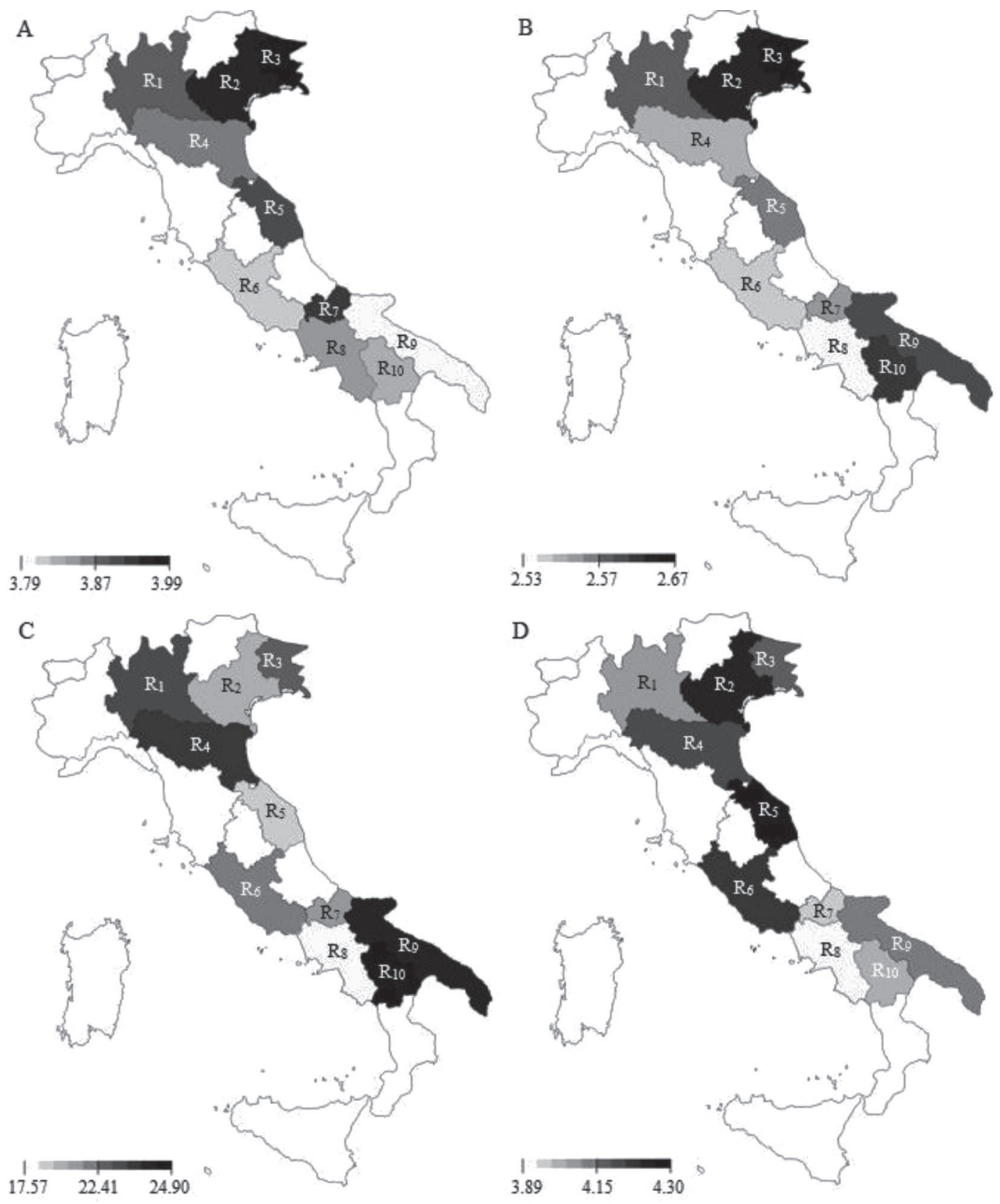

Figure 1. Least squares means of (A) fat percentage, (B) casein percentage, (C) urea content (mg/100 mL), and (D) SCS of bulk milk samples across regions (R). Values are represented in a grayscale where the darkest areas correspond to the greatest values and the lightest areas to the lowest values.

$P<0.001)$. On average, RCT and $\mathrm{k}_{20}$ were lower in the southern and central compared with northern regions. On the other hand, $\mathrm{k}_{20}$ and $\mathrm{a}_{30}$ (Figure $2 \mathrm{C}$ ) showed the opposite trend, which also agrees with the high negative correlation between these 2 traits $(\mathrm{r}=-0.72 ; P<$ 0.001). Finally, TA (Figure 2D) exhibited, in general, a similar pattern to $\mathrm{k}_{20}$ for the northern and southern regions, and a similar pattern to $\mathrm{a}_{30}$ for the central regions. For RCT (Figure 4A) and TA (Figure 4D), the region with the lowest variability was $R_{10}$, and those with the greatest were $R_{7}$ and $R_{3}$ for $R C T$ and $T A$, respectively. For $\mathrm{k}_{20}$ (Figure $4 \mathrm{~B}$ ) and $\mathrm{a}_{30}$ (Figure $4 \mathrm{C}$ ), the greatest variability was observed for $R_{3}$, and the lowest for $R_{2}$ and $R_{1}$, respectively.

On average, northeast (especially $\mathrm{R}_{3}$ ) and centralsouthern regions $\left(R_{5}\right.$ and $\left.R_{7}\right)$ showed the best perfor- 
mance in terms of milk quality and coagulation ability, respectively. Although we did not have access to the breed composition of each herd, the most popular breeds in Italy are Holstein-Friesian, Brown Swiss, and Simmental. On average, regions with a reported predominance of Holstein-Friesian cows $\left(\mathrm{R}_{1}, \mathrm{R}_{4}\right.$, and $\mathrm{R}_{6}$; ANAFI, 2015) exhibited worse milk performance than those where Brown Swiss (ANARB, 2015) and
Simmental breeds (ANAPRI, 2015) are indicated to be more relevant. Several authors have reported that Brown Swiss yields milk with more favorable quality and technological traits than Simmental and, especially, Holstein-Friesian breed (Malacarne et al., 2006; De Marchi et al., 2007; Penasa et al., 2014). As previously reported, the high variability within regions could be because herds differed in terms of average size, milk
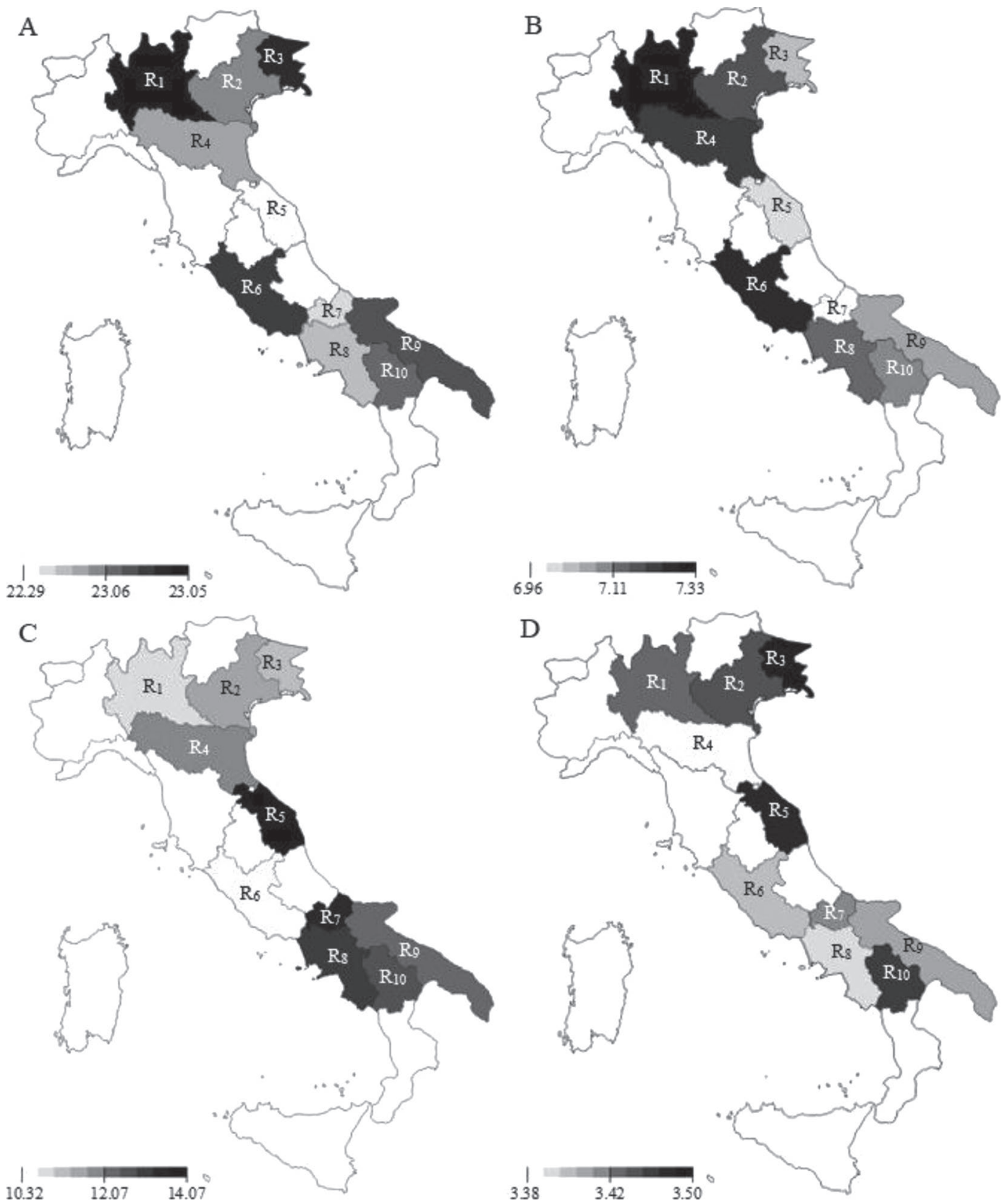

Figure 2. Least squares means of (A) rennet coagulation time (min), (B) curd firming time (min), (C) curd firmness 30 min after rennet addition $(\mathrm{mm})$, and (D) titratable acidity $\left({ }^{\circ} \mathrm{SH} / 50 \mathrm{~mL} ;{ }^{\circ} \mathrm{SH}=\right.$ Soxhlet-Henkel degree) of bulk milk samples across regions (R). Values are represented in a grayscale where the darkest areas correspond to the greatest values and the lightest areas to the lowest values. 
yield, breed composition, management, and feeding strategies. Some authors have observed that differences among farms affected milk quality (Ikonen et al., 2004) and coagulation ability (Toffanin et al., 2012; Penasa et al., 2014). For example, feeding based on concentrates had a positive effect on milk composition and MCP (Tyrisevä et al., 2004). Summer et al. (2014) observed that milk produced in free-stalls had more favorable composition and coagulation characteristics than cows reared in tie-stalls. Recently, De Marchi et al. (2017) reported that automatic milking system increased RCT compared with conventional milking parlor. However, Vallas et al. (2010) observed that milk composition and technological traits of Estonian Holstein cows were not strongly affected by herd.

\section{Season Effect}

Overall, quality traits were more favorable during winter months and worsened in summer, especially July and August (Figure 5A). In these 2 mo, we observed the lowest fat $(3.70 \%)$ and casein $(2.52 \%)$, and the greatest urea content $(24.49 \mathrm{mg} / 100 \mathrm{~mL})$ and SCS
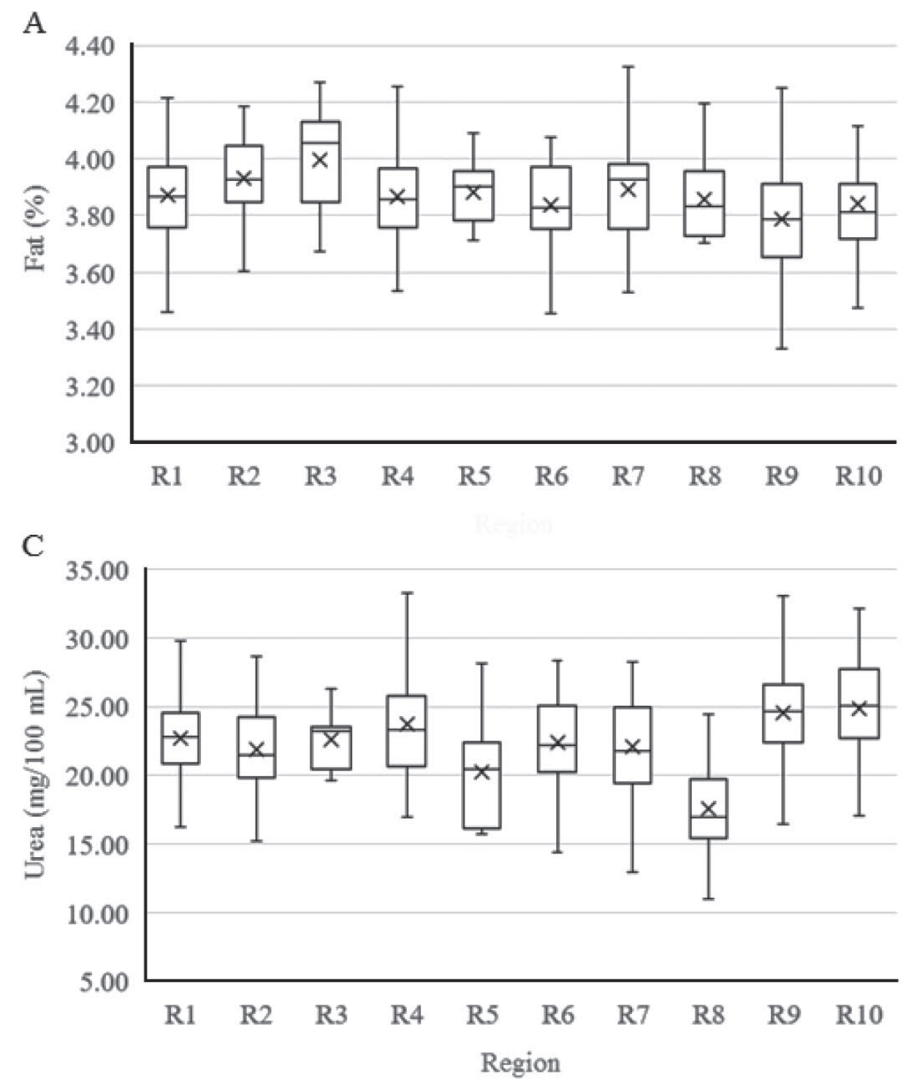

(4.30). Our results agreed with findings of Ng-KwaiHang et al. (1984), who observed that milk composition traits were greater in autumn and winter than in summer. Among traditional traits, urea exhibited the greatest variability across months, ranging from 17.56 $\mathrm{mg} / 100 \mathrm{~mL}$ (November-December) to $24.49 \mathrm{mg} / 100$ mL (July-August). Similarly, Arunvipas et al. (2004) reported higher milk nonprotein nitrogen levels in $\mathrm{Au}-$ gust, September, and October than in colder months. This can be explained through the practice of pasture (Wittwer et al., 1999), but also through the physiological changes related to heat stress. In fact, as reviewed by Hao et al. (2016), heat stress affects protein metabolism, strengthening skeletal muscle catabolism. The latter induces an increment of plasma urea nitrogen, implying that heat stress leads to a redistribution of nitrogen from protein to urea, which increases milk urea content. Moreover, Yadav et al. (2013) reviewed the effect of heat stress on rumen function and digestibility, describing how under prolonged exposure to this condition a reduction of feed intake and an increased water intake occur, with a subsequent dilution of rumen content, reduction of saliva production, decline
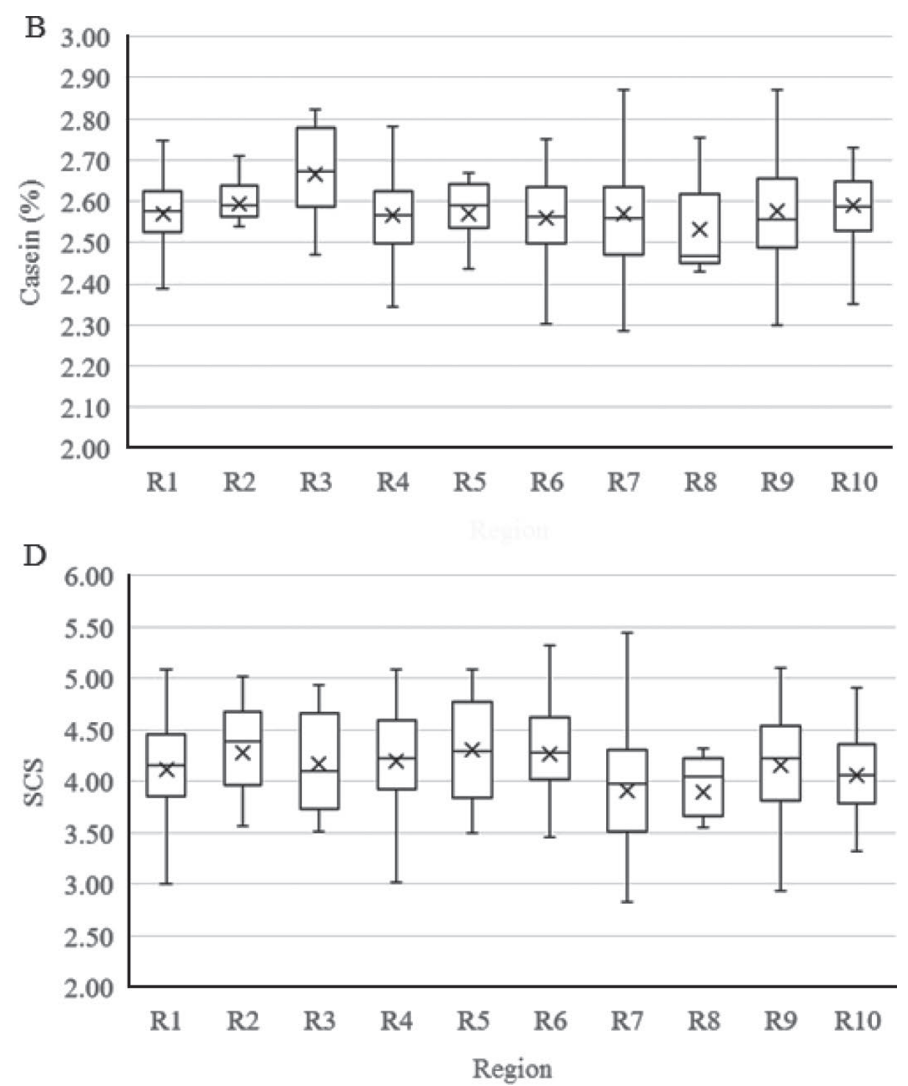

Figure 3. Least squares means of (A) fat percentage, (B) casein percentage, (C) urea content (mg/100 mL), and (D) SCS of bulk milk samples across herds within region (R). Computed LSM are represented as boxes for interquartile range, line for median, whiskers for range, and $\times$ for mean. 
in rumen motility, reduction of bacteria activity, and decreased digestibility. This in turn leads to lower milk yield and impaired milk quality with depression in fat and protein synthesis, including casein, lactalbumin, $\operatorname{IgG}$, and IgA, especially during the summer (Das et al., 2016). Also, the high SCS during the summer could be due to the heat stress caused by the high temperature and humidity that characterize this season, which agrees with Summer et al. (2014).

The $\mathrm{k}_{20}, \mathrm{a}_{30}$, and TA showed more favorable values from November to February (6.78 min, $15.31 \mathrm{~mm}$, and $3.48{ }^{\circ} \mathrm{SH} / 50 \mathrm{~mL}$, respectively) and a deterioration during summer (Figure 5B). The RCT, on the contrary, was more favorable from September to December, and worsened during the following months $(24.00 \mathrm{~min})$. The $\mathrm{k}_{20}$ and TA were almost constant across seasons. Malacarne et al. (2005), De Marchi et al. (2007), and Penasa et al. (2016) have also reported favorable technological traits during autumn and winter, and a deterioration of milk coagulation ability during summer.
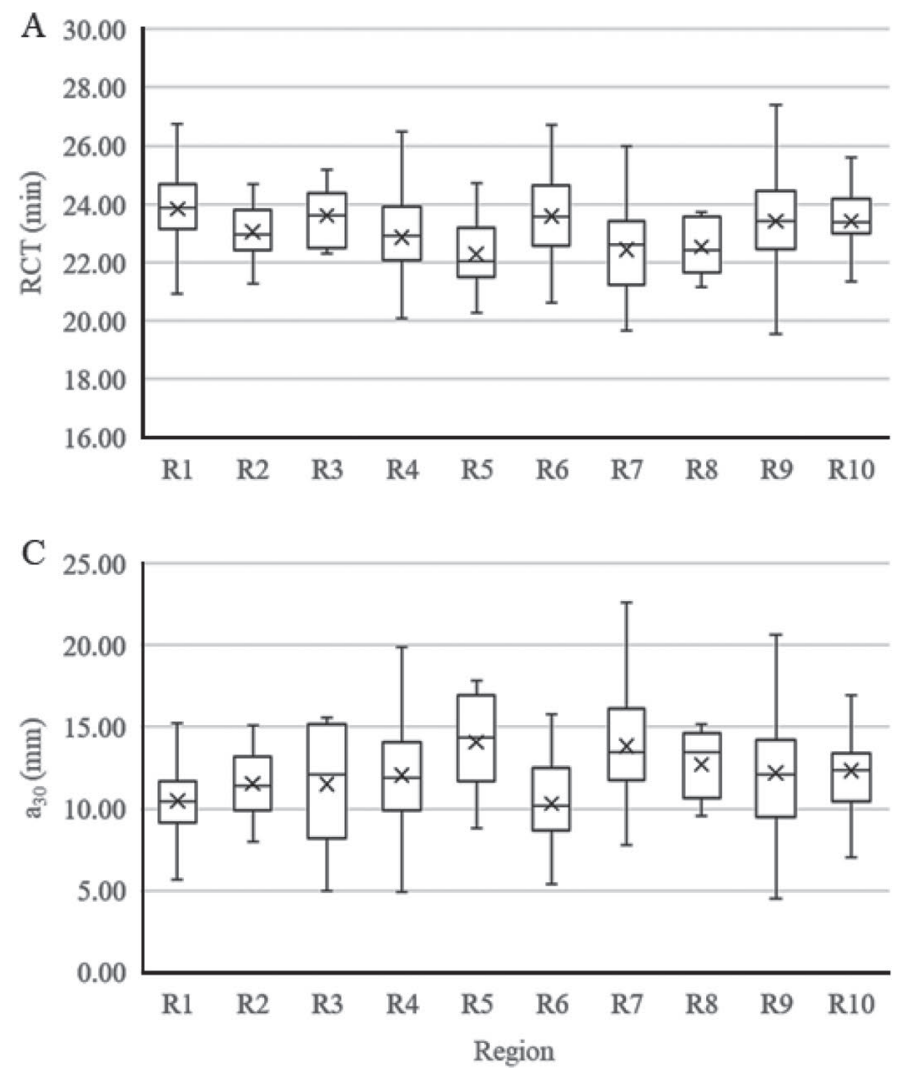

\section{CONCLUSIONS}

Results of the present study highlighted the good quality of milk collected by Granarolo S.p.A. dairy industry in terms of fat, protein, and casein percentages, and less favorable findings in terms of SCS and MCP. For the first time, field data of milk coagulation traits and acidity predicted by mid-infrared spectroscopy during routine milk recording for payment purposes were analyzed. Statistical analysis revealed that region, herd within region, and season of milk analysis significantly influenced milk quality, coagulation traits, and TA. For a given trait, it was possible to define the best and the worst regions. This evidence could be used to segregate bulk milk in relation to its dairy manufacturing, and to consider rewarding milk producers based on milk technological traits. Further research should investigate thoroughly the causes of variation between regions and farms including relevant information on herd management and breeds.
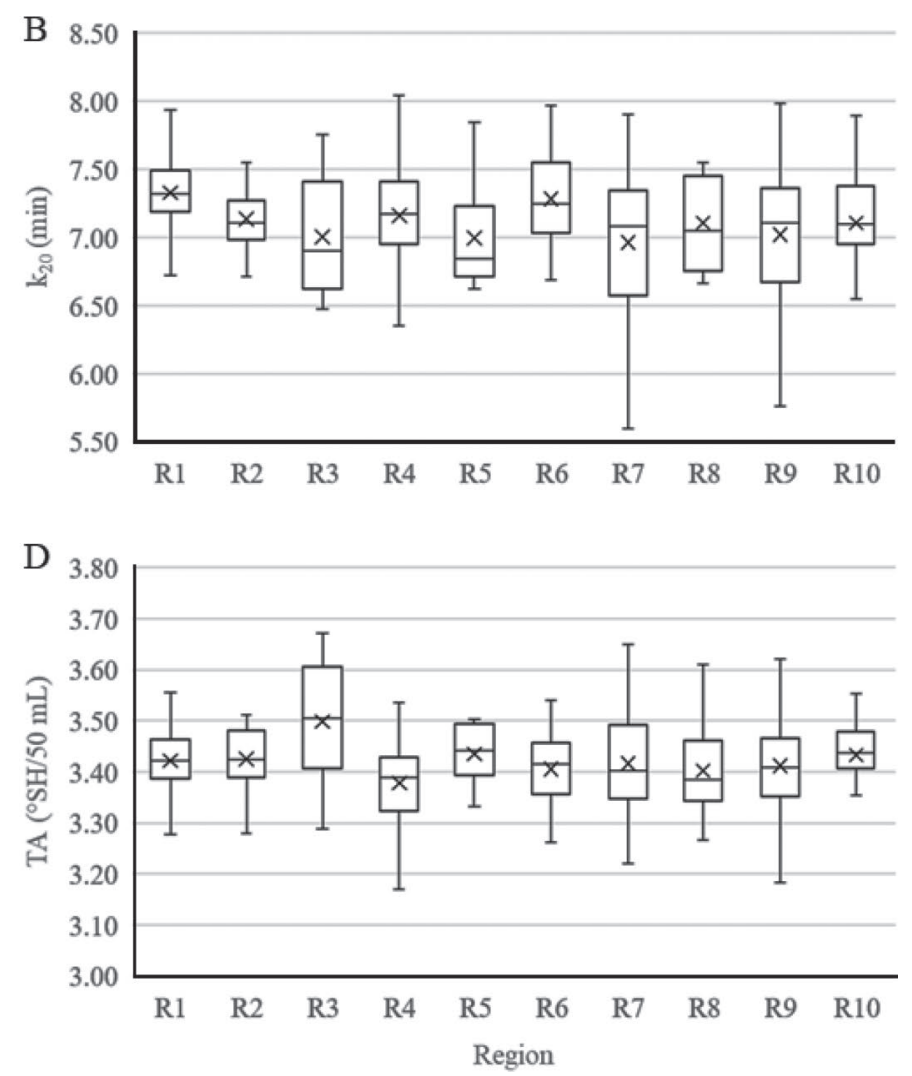

Figure 4. Least squares means of (A) rennet coagulation time (RCT; min), (B) curd firming time $\left(\mathrm{k}_{20} ;\right.$ min), (C) curd firmness 30 min after rennet addition $\left(\mathrm{a}_{30} ; \mathrm{mm}\right)$, and $(\mathrm{D})$ titratable acidity $\left(\mathrm{TA} ;{ }^{\circ} \mathrm{SH} / 50 \mathrm{~mL} ;{ }^{\circ} \mathrm{SH}=\right.$ Soxhlet-Henkel degree) of bulk milk samples across herds within region. Computed LSM are represented as boxes for interquartile range, line for median, whiskers for range, and $\mathrm{x}$ for mean. 


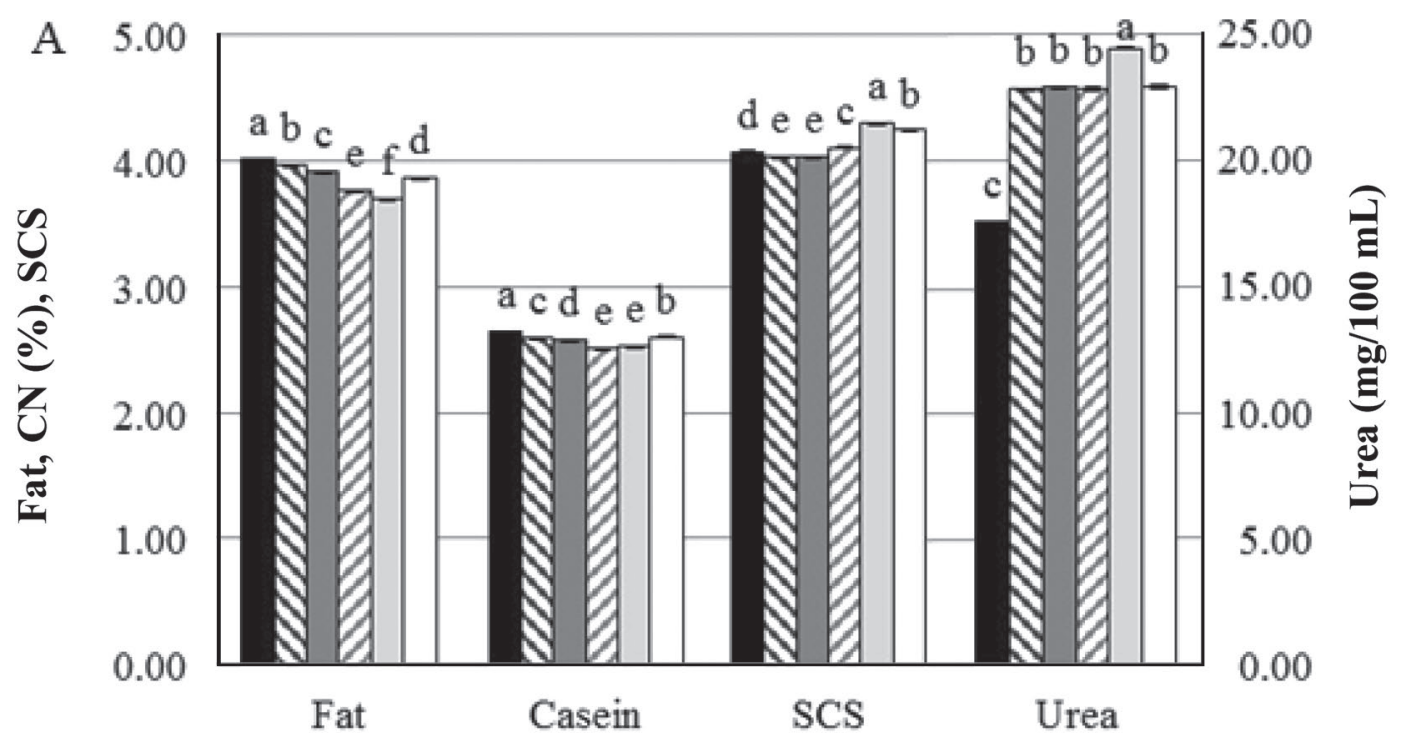

Nov-Dec \$ Jan-Feb $\square$ Mar-Apr $\square$ May-Jun $\square$ Jul-Aug $\square$ Sep-Oct

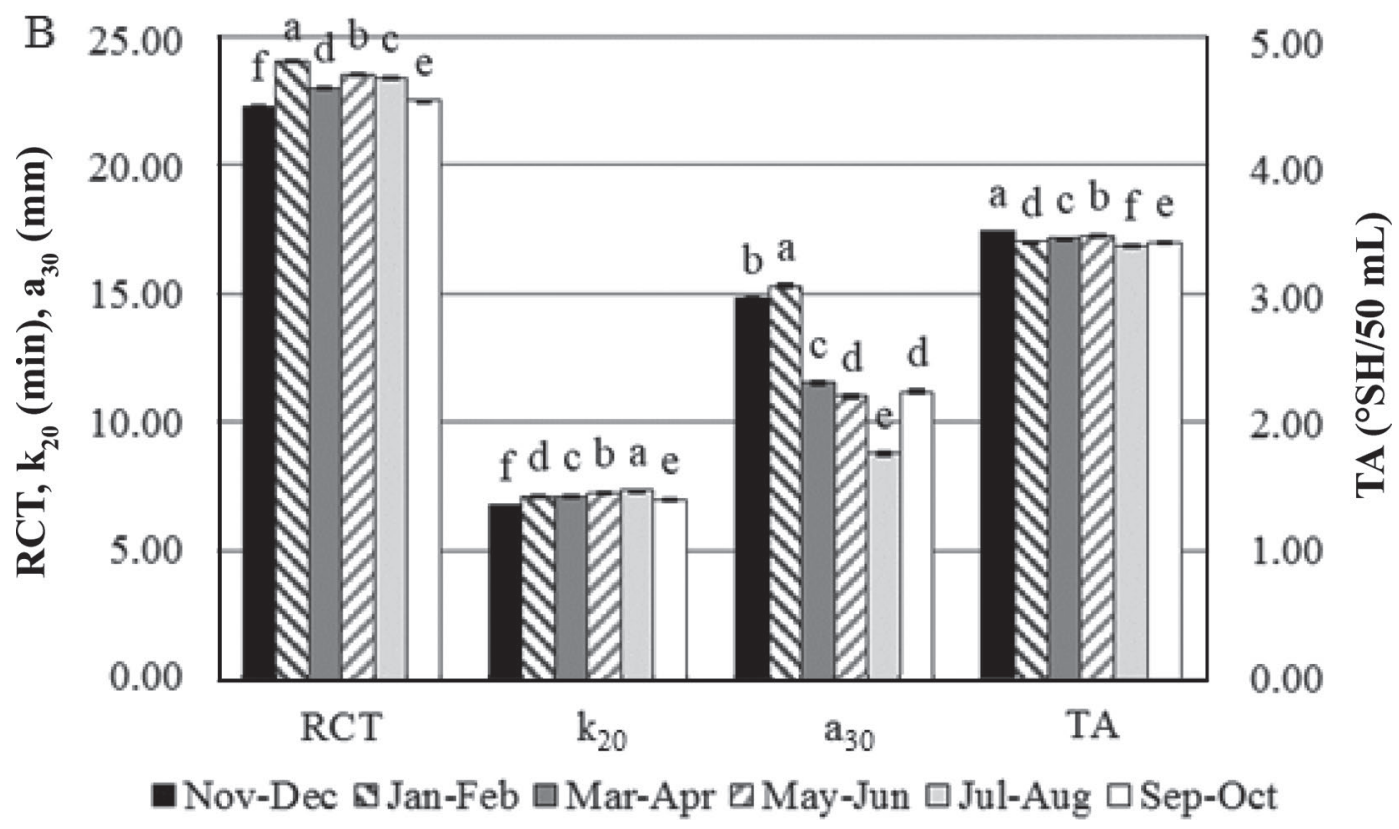

Figure 5. Least squares means and SE of (A) milk quality traits and (B) milk technological traits across months. ${ }^{\circ} \mathrm{SH}=\mathrm{Soxhlet-Henkel} \mathrm{de-}$ gree; $\mathrm{RCT}=$ rennet coagulation time; $\mathrm{k}_{20}=$ curd firming time; $\mathrm{a}_{30}=$ curd firmness 30 min after rennet addition to milk; TA $=$ titratable acidity. Least squares means with different letters within a trait are significantly different according to Bonferroni's test $(P<0.05)$.

\section{ACKNOWLEDGMENTS}

The authors gratefully acknowledge Granarolo S.p.A. (Bologna, Italy) for providing data used in this study.

\section{REFERENCES}

AIA (Associazione Italiana Allevatori). 2015. Bollettino dei controlli della produttività del latte 2015. Accessed Dec. 10, 2016. http:// bollettino.aia.it/bollettino/bollettino.htm.
ANAFI (Associazione Nazionale Allevatori Frisona Italiana). 2015 Official Statistics. Accessed Jan. 11, 2017. http://www.anafi.it/ english/.

ANAPRI (Associazione Nazionale Allevatori Bovini di Razza Pezzata Rossa Italiana). 2015. Official Statistics. Accessed Jan. 11, 2017. http://www.anapri.eu/index.php?option=com_content\&view $=$ article\&id=192: consistenze-2015\&catid=1:ultime.

ANARB (Associazione Nazionale Allevatori Razza Bruna). 2015. Official Statistics. Accessed Jan. 11, 2017. http://www.anarb.it/ pagina.asp? $\mathrm{ID}=2508$ \&lang $=$ it .

Arunvipas, P. J. A. VanLeeuwen, I. R. Dohoo, and G. P. Keefe. 2004 Bulk tank milk urea nitrogen: Seasonal patterns and relationship 
to individual cow milk urea nitrogen values. Can. J. Vet. Res. 68:169-174.

Bittante, G., M. Penasa, and A. Cecchinato. 2012. Invited review: Genetics and modeling of milk coagulation properties. J. Dairy Sci. 95:6843-6870.

Cassandro, M. 2003. Status of milk production and market in Italy. Agric. Conspec. Sci. 68:65-69.

Cassandro, M., A. Comin, M. Ojala, R. Dal Zotto, M. De Marchi, L. Gallo, P. Carnier, and G. Bittante. 2008. Genetic parameters of milk coagulation properties and their relationships with milk yield and quality traits in Italian Holstein cows. J. Dairy Sci. 91:371376.

Cassandro, M., D. Pretto, N. Lopez-Villalobos, M. De Marchi, and M. Penasa. 2016. Estimation of economic values for milk coagulation properties in Italian Holstein-Friesian cattle. J. Dairy Sci. 99:6619-6626.

Comino, L., F. Righi, M. Coppa, A. Quarantelli, E. Tabacco, and G. Borreani. 2015. Relationships among early lactation milk fat depression, cattle productivity and fatty acid composition on intensive dairy farms in Northern Italy. Ital. J. Anim. Sci. 14:350-361.

Das, R., L. Sailo, N. Verma, P. Bharti, J. Saikia, Imtiwati, and R. Kumar. 2016. Impact of heat stress on health and performance of dairy animals: A review. Vet. World 9:260-268.

De Marchi, M., G. Bittante, R. Dal Zotto, C. Dalvit, and M. Cassandro. 2008. Effect of Holstein Friesian and Brown Swiss breeds on quality of milk and cheese. J. Dairy Sci. 91:4092-4102.

De Marchi, M., R. Dal Zotto, M. Cassandro, and G. Bittante. 2007. Milk coagulation ability of five dairy cattle breeds. J. Dairy Sci. 90:3986-3992.

De Marchi, M., M. Penasa, and M. Cassandro. 2017. Comparison between automatic and conventional milking systems for milk coagulation properties and fatty acid composition in commercial dairy herds. Ital. J. Anim. Sci. 16:363-370.

De Marchi, M., M. Penasa, F. Tiezzi, V. Toffanin, and M. Cassandro. 2012. Prediction of milk coagulation properties by Fourier Transform Mid-Infrared Spectroscopy (FTMIR) for genetic purposes, herd management and dairy profitability. Pages $47-53$ in Proc. 38th International Committee for Animal Recording (ICAR) Meeting, Cork, Ireland. ICAR, Rome, Italy.

De Marchi, M., V. Toffanin, M. Cassandro, and M. Penasa. 2013. Prediction of coagulating and noncoagulating milk samples using mid-infrared spectroscopy. J. Dairy Sci. 96:4707-4715.

Hao, L., J. Wang, P. Sun, and D. Bu. 2016. The effect of heat stress on the metabolism of dairy cows: Updates \& review. Austin J. Nutr. Metab. 3:1-5.

Ikonen, T., S. Morri, A.-M. Tyriseva, O. Ruottinen, and M. Ojala. 2004. Genetic and phenotypic correlations between milk coagulation properties, milk production traits, somatic cell count, casein content, and pH of milk. J. Dairy Sci. 87:458-467.

ISMEA (Istituto di Servizi per il Mercato Agricolo Alimentare). 2016. Lattiero caseari: tendenze e dinamiche recenti. Accessed Dec. 16, 2016. http://www.ismeamercati.it/flex/cm/pages/ServeBLOB .php/L/IT/IDPagina/7207.

Jõudu, I., M. Henno, T. Kaart, T. Püssa, and O. Kärt. 2008. The effect of milk protein contents on the rennet coagulation properties of milk from individual dairy cows. Int. Dairy J. 18:964-967.

Malacarne, M., S. Fieni, F. Tosi, P. Franceschi, P. Formaggioni, and A. Summer. 2005. Seasonal variations of the rennet-coagulation properties of herd milks in Parmigiano-Reggiano cheese manufacture: Comparison between Italian Friesian and Italian Brown cattle breeds. Ital. J. Anim. Sci. 4(Suppl. 2):215-217.

Malacarne, M., A. Summer, E. Fossa, P. Formaggioni, P. Franceschi, M. Pecorari, and P. Mariani. 2006. Composition, coagulation prop- erties and Parmigiano-Reggiano cheese yield of Italian Brown and Italian Friesian herd milks. J. Dairy Res. 73:171-177.

Ng-Kwai-Hang, K. F., J. F. Hayes, J. E. Moxley, and H. G. Monardes. 1984. Variability of test-day milk production and composition and relation of somatic cell counts with yield and compositional changes of bovine milk. J. Dairy Sci. 67:361-366.

Penasa, M., F. Tiezzi, A. Sturaro, M. Cassandro, and M. De Marchi. 2014. A comparison of the predicted coagulation characteristics and composition of milk from multi-breed herds of Holstein-Friesian, Brown Swiss and Simmental cows. Int. Dairy J. 35:6-10.

Penasa, M., V. Toffanin, N. Cologna, M. Cassandro, and M. De Marchi. 2016. Effects of dairy factory, milk casein content and titratable acidity on coagulation properties in Trentingrana dairy industry. J. Dairy Res. 83:242-248.

Pieri, R. 2014. Il mercato del latte. Rapporto 2014. Franco Angeli, Milano, Italy.

Pretto, D., M. De Marchi, M. Penasa, and M. Cassandro. 2013. Effect of milk composition and coagulation traits on Grana Padano cheese yield under field conditions. J. Dairy Res. 80:1-5.

Rajala-Schultz, P. J., and W. J. A. Saville. 2003. Sources of variation in milk urea nitrogen in Ohio dairy herds. J. Dairy Sci. 86:16531661.

Righi, F., A. Quarantelli, L. Tonelli, M. Renzi, and B. Gandolfi. 2007. Use of Penn State Particle Separator for the evaluation of total mixed rations typical of Parmigiano Reggiano cheese production area. Ital. J. Anim. Sci. 6(Suppl. 1):347-349

Summer, A., P. Franceschi, P. Formaggioni, and M. Malacarne. 2014 Characteristics of raw milk produced by free-stall or tie-stall cattle herds in the Parmigiano-Reggiano cheese production area. Dairy Sci. Technol. 94:581-590.

Summer, A., P. Franceschi, P. Formaggioni, and M. Malacarne. 2015. Influence of milk somatic cell content on Parmigiano-Reggiano cheese yield. J. Dairy Res. 82:222-227.

Summer, A., M. Malacarne, F. Martuzzi, and P. Mariani. 2002. Structural and functional characteristics of Modenese cow milk in Parmigiano-Reggiano cheese production. Annali della Facoltà di Medicina Veterinaria Università degli Studi di Parma 22:163-174.

Tiezzi, F., D. Pretto, M. De Marchi, M. Penasa, and M. Cassandro. 2013. Heritability and repeatability of milk coagulation properties predicted by mid-infrared spectroscopy during routine data recording, and their relationships with milk yield and quality traits. Animal 7:1592-1599.

Toffanin, V., M. De Marchi, N. Lopez-Villalobos, and M. Cassandro. 2015. Effectiveness of mid-infrared spectroscopy for prediction of the contents of calcium and phosphorus, and titratable acidity of milk and their relationship with milk quality and coagulation properties. Int. Dairy J. 41:68-73.

Toffanin, V., M. De Marchi, M. Penasa, D. Pretto, and M. Cassandro. 2012. Characterization of milk coagulation ability in bulk milk samples. Acta Agric. Slov. 100:93-98.

Tyrisevä, A.-M., T. Vahlsten, O. Ruottinen, and M. Ojala. 2004. Noncoagulation of milk in Finnish Ayrshire and Holstein-Friesian cows and effect of herds on milk coagulation ability. J. Dairy Sci. 87:3958-3966.

Vallas, M., H. Bovenhuis, T. Kaart, K. Pärna, H. Kiiman, and E. Pärna. 2010. Genetic parameters for milk coagulation properties in Estonian Holstein cows. J. Dairy Sci. 93:3789-3796.

Wittwer, F. G., P. Gallardo, J. Reyes, and H. Opitz. 1999. Bulk milk urea concentrations and their relationship with cow fertility in grazing dairy herds in Southern Chile. Prev. Vet. Med. 38:159-166.

Yadav, B., G. Singh, A. K. Verma, N. Dutta, and V. Sejian. 2013 Impact of heat stress on rumen functions. Vet. World 6:992-996. 